\title{
Adam Węgrzecki, "Wokół filozofii spotkania”, Wydawnictwo WAM, Kraków 2014, ss. 224
}

DOI: http://dx.doi.org/10.12775/RF.2014.035

Filozofia spotkania trafiła w Polsce na podatny grunt. Zajmuje się nią coraz więcej osób, kwestią czasu było więc pojawienie się pierwszej książki syntetyzującej ten nurt myślowy ze szczególnym uwzględnieniem dorobku rodzimych twórców, których z roku na rok przybywa.

Tego zadania podjął się sam uprawiający ją od dawna profesor Adam Węgrzecki i wykonał je w charakterystyczny dla siebie sposób: rzetelnie, dogłębnie, a zarazem w sposób nader przystępny, czyli pozwalający przybliżyć tę z pozoru tylko łatwą problematykę również ludziom nierozważającym na co dzień skomplikowanych zagadnień z pogranicza metafizyki, epistemologii, aksjologii, etyki czy antropologii filozoficznej.

Jego wydana przez WAM rozprawa pt. Wokót filozofii spotkania skonstruowana jest niezwykle przejrzyście. Autor skupił się w niej na dokładnym przedstawieniu poszczególnych koncepcji, sporach między reprezentującymi je myślicielami, dokonał także wielu precyzyjnych rozróżnień pojęciowych.

Jako pierwszym z nich zajął się niedostrzeganą przez wielu albo celowo pomijaną bądź nawet lekceważoną różnicą pomiędzy filozofią spotkania a filozofią dialogu. Trafnie zauważył, że jeżeli pojmuje się spotkanie w sposób bardziej pogłębiony, znaczeniowo oddala się ono od dialogu, chociaż nie jest czymś od niego odrębnym.

„W spotkaniu możliwie pełnym i autentycznym dialog nie tylko może wystąpić, ale wręcz trudno sobie wyobrazić, aby do niego nie doszło. Gdyby go zabrakło, można by nawet uznać, że nie nastąpiła w nim wzajemna prezentacja siebie przez uczestników spotkania" - napisał Węgrzecki.

Dialog nie musi jednak oznaczać wyłącznie komunikacji werbalnej, może zaistnieć w postaci gestów, sposobów zachowań, bardziej lub mniej udanej prezentacji własnych uczuć. Wszelkie jego formy mają jak najlepiej służyć temu, co Gabriel Marcel nazywał otwarciem drugiemu człowiekowi kredytu zaufania, a Józef Tischner postawa, w której na 
różne sposoby chcę przekonać bliźniego, że nie skrzywdzę go i nie uczynię mu żadnej krzywdy, niecnie wykorzystując to, że mi zawierzył.

Dlatego też zdaniem Węgrzeckiego „dialog jest formą komunikacji między ludźmi, służącą jej rozszerzeniu i pogłębieniu i pomocną w osiąganiu porozumienia", podczas gdy spotkanie „ma przede wszystkim umożliwić pełniejsze wzajemne zaistnienie i zaprezentowanie się sobie uczestniczących w nim osób".

Zwracam uwagę na pojęcie „wzajemnego zaistnienia”, które jest znacznie mocniejsze od „wzajemnego poznawania się" i przenosi nas z epistemologii do metafizyki. W swoich wcześniejszych pracach o filozofii spotkania Węgrzecki wszechstronnie analizował poznawczy wymiar tej relacji międzyludzkiej, obecnie wyraźnie przenosi ją na grunt ontologii i antropologii, co stanowi kontynuację myśli Martina Bubera i przywołanego już Marcela konsekwentnie twierdzących - wbrew twórcom egzystencjalizmu - iż każde istnienie jest faktycznie współistnieniem, a stosunki międzyludzkie mogą być oparte na równości podmiotów, nie zaś - jak chciał Jean Paul Sartre - na nienawiści prowadzącej do wzajemnego, naprzemiennego uprzedmiatawiania się.

Autor obszernie i bardzo wnikliwie analizuje spotkanie, używając metody i terminologii fenomenologicznej (jest przecież uczniem Romana Ingardena), podkreślając jego osobowy i partnerski charakter. Spotykać moga się tylko konkretne, indywidualne osoby, co moim zdaniem nie wyklucza możliwości przeżywania spotkań także z Bogiem, oczywiście traktowanym jako Osoba Osób, a nie transcendentny absolut. Trochę zabrakło mi w książce Węgrzeckiego odniesienia do tego zagadnienia.

$\mathrm{W}$ rozdziale poświęconym roli poznawania w spotkaniu bardzo ważne jest rozróżnienie pomiędzy pośrednim a bezpośrednim dostępem do drugiego człowieka. W spotkaniu występuje tylko ta druga forma, która jest ze względu na swoją bardziej intuicyjną niż intelektualną naturę dosyć skomplikowana i wymyka się próbom dokładnego opisania.

Autor swobodnie przedstawia te trudne problemy i próby ich przezwyciężenia na przykładzie pojęcia „wczucia” używanego przez Edmunda Husserla i przez Edytę Stein, a także współodczuwania oraz innych przeżyć intencjonalnych opisanych przez Maxa Schelera, którego twórczości jest wielkim znawcą. Zdając sobie sprawę z trudności, jakie wiążą się z tymi pojęciami Węgrzecki podkreśla, że jest to jedyna droga do prawdziwego spotkania, w którym chodzi nam $\mathrm{z}$ jednej strony o jak najlepsze zrozumienie drugiego człowieka, z drugiej zaś o uszanowanie jego podmiotowości; wyciągnięta z ufnością i dobrą wolą ręka może być bowiem potraktowana przez niego w zupełnie odmienny od mojej intencji sposób.

Podobne wyzwania przynoszą czas i przestrzeń, w jakich dzieje się spotkanie. Celowo użyłem określenia „dzieje się", ponieważ Węgrzecki podkreśla procesualny charakter owego fenomenu. Nie jest to więc na- 
głe i zazwyczaj krótkie wydarzenie, aczkolwiek proces spotykania często składa się z takich właśnie momentów. Oprócz fizycznej i kulturowej autor podkreśla przestrzeń własną spotkania, którą wyznacza to, co kryje się w słowie „między”. Zwraca też uwagę na to, iż partnerami nie muszą być osoby równorzędne, a bliskość oznacza "osiągnięcie w spotkaniu znacznej przejrzystości i jednoznaczności w manifestowaniu siebie".

Węgrzecki jest czołowym w Polsce specjalistą od aksjologii i antropologii filozoficznej, rozdział o wartościach w spotkaniu jest więc prawdziwą perełka, chociaż nieźle byłoby sięgnąć do jego wcześniejszych prac z tej dziedziny, aby jeszcze lepiej dostrzec horyzonty, o których w nim mowa. Szczególną uwagę zwraca fragment poświęcony ocenianiu drugiego człowieka, które jest zarazem odsłonięciem systemu wartości oceniającego. Zawsze trzeba pamiętać o zachowaniu szczególnej delikatności, bo inaczej zdegraduje się bliźniego do roli przedmiotu, co konsekwentnie czynił w swoich dziełach Sartre. Równie niebezpieczne jest jednak niedocenienie będące sposobem zubożenia drugiego, odebrania mu czegoś, czym się odznacza i co jest mu bardzo drogie. Autor dostrzega też "odwrotną stronę”, czyli konieczność dokonania niekiedy zmian we własnym systemie wartości pod wpływem spotkania.

Odwołując się do terminologii filozoficznej Martina Heideggera można powiedzieć, że spotkanie jest jednym z przejawów autentycznego bycia, w którym odrzuca się bierną i oportunistyczną postawę man lebt. Jeżeli chcę spotkać drugiego człowieka, muszę wykazać się nie lada odwagą i gotowością do przekroczenia dotychczasowych horyzontów: aksjologicznego i agatologicznego, chociaż nigdy nie wiem, czy osiągnę zamierzony cel, ani jak zostanę potraktowany przez potencjalnego partnera. Dlatego też Węgrzecki wielokrotnie przypomina, że spotkania nie można się nauczyć i że jest ono nieprzewidywalnym wydarzeniem w życiu każdego z nas. Za dokonującym się w nim "przekroczeniem siebie” otwierają się zupełnie nowe perspektywy nadające sens temu, co pierwotnie często traktowałem wyłącznie w kategoriach niefrasobliwego ryzyka. Poczucie spełnienia wynagradza uprzednie wątpliwości i wahania.

Na początku ostatniego rozdziału Węgrzecki jednoznacznie stwierdza, że "spotkanie jest fenomenem par excellence antropologicznym, ukazującym to, co dzieje się i może się dziać z człowiekiem", gdy spotka się z drugim w sposób autentyczny i niepozorowany. Jak zaznaczył wcześniej, trzeba $\mathrm{w}$ tym celu zrzucić maski i zasłony (ulubione pojęcia Emmanuela Levinasa wprowadzone do polskiej filozofii przez Tischnera), aczkolwiek nigdy nie ma pewności, czy jest to szczerze i do końca spełnione zamierzenie. Bywa i odwrotnie: nieoczekiwane i poruszające całą osobowość człowieka spotkanie powoduje, że spadają one nawet wbrew jego woli.

Autor z ugruntowanym we wcześniejszych analizach przekonaniem twierdzi, że spotkanie ,jest niejako zaproszeniem do wspólnego zmagania się z problemami, często mającymi istotne znaczenie $\mathrm{w}$ budowaniu 
samego siebie” i że niekiedy sprawia ono, iż „w bycie człowieka następuje istotna zmiana”, a wychodzi on z niego "z pełniejszą samowiedza, z lepszym rozwiązaniem własnych możliwości, a także trudności w realizowaniu własnego projektu życiowego, w budowaniu siebie i swej osobowej tożsamości".

Zdaniem Węgrzeckiego spotkanie jest także istotnym źródłem antropologicznych określeń poznawczych i ontycznych, pozwalając człowiekowi na lepsze rozpoznanie siebie, ale zarazem budząc w nim nadzieję na pogłębienie zrozumienia własnej osoby (głównie bezpośrednio), a także okazania gotowości do przekroczenia wiążących go do tej pory ograniczeń. Zanim nie spotkał on drugiej osoby albo nie znał owych przeszkód w ambitnej drodze ku najwyższym wartościom, albo uważał je za nieprzezwyciężalne, co mogło prowadzić go nawet na skraj depresji i choroby psychicznej. Nie bez powodu jednym z często przywoływanych przez Węgrzeckiego autorów jest Antoni Kępiński.

Spotkanie może pomóc człowiekowi stać się sobą i zarazem osobą. W fenomenologicznym warsztacie Węgrzeckiego można zauważyć również personalistyczne sympatie, ale tylko w ich poważnym, filozoficznym ujęciu, a nie w socjologicznych, a nawet politologicznych dywagacjach, w jakie lubił wdawać się Emmanuel Mounier.

Autor książki nie przecenia roli spotkania w procesie „dochodzenia do siebie", ale równocześnie w pełni je docenia. Efekty metafizyczne, epistemologiczne, aksjologiczne i etyczne, które zawdzięczamy spotkaniu są możliwe do osiągnięcia także na innych drogach, ale to właśnie ono "stwarza rozliczne okazje do odkrywania w sobie czegoś, co poza spotkaniem mogłoby się w ogóle nie ujawnić", a także "do odkrycia w sobie pewnej, dotąd nieuwidacznianej potencji do bycia właśnie taką a taką osoba, do zaznaczenia siebie jako osoby o takim jakościowym określeniu, z którym skłonna jest się identyfikować". Dlatego właśnie spotkanie ma „tożsamościowotwórczy” charakter, które to określenie zapożyczył Węgrzecki od Joanny Trzupek.

Końcowe fragmenty pierwszej części książki (drugą stanowi wybór dwunastu wcześniejszych prac o filozofii spotkania publikowanych przez autora od 1978 roku) stanowią zwięzłe i logicznie wywiedzione z jego uprzednich rozważań konstatacje, z których wybieram na podsumowanie jedna, szczególnie sugestywną:

„Od spotkań, zwłaszcza autentycznych, realnych i pełnych, w ogromnej wierze zależy jakość życia. Jeśli ich brakuje, staje się ono znacznie uboższe i jednostronne. Ale jeśli przynoszą doświadczenia pomocne w przezwyciężaniu trudności i przeciwieństw losu, jeśli pozwalają pogłębić rozumienie ludzi i otaczającej rzeczywistości - wydatnie podnoszą jakość życia". 